\title{
URGENSI ETIKA DALAM AKUNTANSI DILIHAT DARI SUDUT PANDANG ISLAM
}

\author{
Harkaneri
}

\begin{abstract}
Abstrak
Banyaknya kasus pelanggaran etika dalam bisnis dan profesi baik yang terjadi di tingkat Internasional maupun nasional menunjukkan adanya krisis moral dari pelaku binis dan profesi tersebut. Sementara profesi akuntan adalah profesi yang membutuhkan kepercayaan dari masyarakat. Oleh sebab itu etika sangat diperlukan dalam akuntansi tersebut sehingga kepercayaan ini dapat dijaga dan dipertahankan. Tulisan ini mencoba menjelaskan pentingnya etika dalam akuntansi, yang diuraikan berdasarkan sudut pandang Islam. Karena Islam adalah agama Universal, yang mengatur seluruh kehidupan termasuk masalah akuntansi dan bisnis. Dalam makalah ini dijelaskan bagaimana Islam menekankan betapa pentingnya etika dalam akuntansi. Jika hal ini dilakukan dan dilaksanakan, maka kasus kecurangan dan kasus pelanggaran etika lainnya yang terjadi dalam bisnis dan profesi dapat dicegah dan dihindari.
\end{abstract}

Kata kunci: etika, akuntansi, dan Islam.

\section{Pendahuluan}

Dalam beberapa tahun belakangan ini, kita mendengar dan menyaksikan banyaknya skandal dan kasus-kasus kecurangan yang terjadi di perusahaan besar yang melibatkan akuntan. Kita juga dapat menyaksikan betapa besarnya dampak kerugian masyarakat yang ditimbulkan oleh penyalahgunaan keahlian dalam membuat informasi akuntansi yang menyesatkan. Sampai saat ini kita masih dihadapi oleh berita-berita yang mengabarkan makin maraknya skandal bisnis dalam berbagai bentuk manipulasi laporan keuangan yang melibatkan para akuntan dan eksekutif puncak perusahaan-perusahaan besar berskala global yang merugikan banyak pihak yang berkepentingan.

Sebagai contoh kasus Enron (Tonge dkk., 2003) yang melibatkan akuntan publik Arthur Anderson (Doost \& Fishman, 2004). Kemudian menurut Wilopo (2010) kasus kecurangan yang dilakukan oleh manajemen puncak perusahaan Enron, World Com, Xerox dan lainnya membuat pasar saham dan keuangan New York Stock Exchange dan berbagai bursa efek di awal tahun 2000an rontok. Selain itu Amerika juga kehilangan milyaran dolar investasinya, lapangan kerja lenyap dan ribuan orang kehilangan simpanan pensiunnya ( Schroeder dkk, 2009 ).

Khera (2001) dalam Wilopo (2010) mengutip hasil penelitian Etzioni menjelaskan bahwa terdapat berbagai temuan eksekutif US dalam bentuk kejahatan, seperti kolusi harga, penipuan informasi dan pencurian teknologi. Akibatnya gejolak publik atas isu ini berakibat pada jajak pendapat di depan kongres, dan pada 25 April 2002 House of Representatif meluluskan undang-undang Oxley dan pada 15 Juli 2002 senat meluluskan undang-undang Sarbanes yang kemudian keduanya dikenal sebagai Akta Sarbanes Oxley tahun 2002 (SOS), yang ditandatangani Presiden George W.Bush pada 30 Juli 2002 ( Schroeder dkk, 2009 ).

Selain kasus di atas Wilopo (2010) juga menambahkan bahwa terdapat penipuan pajak di USA oleh 
Chevron dan Texaco kerjasama dengan pemerintah Indonesia (Gramllch dan Wheeler 2003). Di Indonesia terjadi kecurangan dalam likuidasi perbankan tahun 1997 - 1999 (Wilopo, 2001). Perekayasaan laba oleh perusahaan manufaktur yang go publik di Bursa Efek Jakarta (Mayangsari \& Wilopo, 2002) dan perekayasaan laba oleh PT. Indofarma, Tbk tahun 2004 (Info Bapepam 2004).

Sementara itu di tahun 2009, Bernard L. Madoff, mantan "CEO NASDAG" (Bursa Saham untuk bidang Teknologi Informasi terbesar di dunia) di Amerika Serikat melakukan manipulasi informasi yang merugikan para investor sejumlah US 150 milard (Wilopo, 2010). Dan di Indonesia sendiri, kita sekarang lagi dihebohkan oleh sejumlah kasus korupsi, kolusi, manipulasi dan penyuapan baik yang terjadi di kalangan pemerintahan, perbankan maupun di legislatif, baik yang dilakukan oleh para pejabat dan petinggi maupun yang dilakukan oleh pegawai atau karyawan.

Hal ini semua menunjukkan kepada kita betapa umat manusia sekarang ini sedang mengalami krisis moral. Keserakahan manusia terhadap harta kekayaan dan keuntungan material membuat manusia menjadi lupa terhadap aturan dan norma-norma (etika) sehingga merugikan kepentingan umum yang pada akhirnya juga merugikan dirinya sendiri.

Graffikin (2008- hal 167), menyatakan bahwa ketika menguji isu etika ada beberapa pertimbangan moral yang berpengaruh pada pengertian etika yaitu : agama (teori perintah Tuhan ), kata hati, egoisme, respek, hak, utilitariansme, keadilan dan kebaikan. Etika dalam profesi akuntan sendiri sudah terdapat etika profesi, akan tetapi etika ini dibangun atas rasionalisme sekuler dan ternyata tidak mampu menghindari nafsu keserakahan manusia terhadap keuntungan material itu.
Akuntansi sendiri dilahirkan untuk membantu kapitalis meraih keuntungan yang sebesar-besarnya (Harahap, 2008).

Menurut Triyuwono (2006), akuntansi modern tidak mampu merefleksikan realitas non-ekonomi yang diciptakan perusahaan. Ia hanya mampu mengakui dan merefleksikan peristiwa ekonomi yang bersifat private costs/benefits dan tidak mampu mengakui public costs/benefits. Dengan orientasi memaksimalkan profit untuk kepentingan shareholdersnya atau untuk kepentingan manajemen sendiri seperti untuk mendapatkan bonus, maka manajemen melakukan eksploitasi terhadap orang lain dan lingkungan alam (Triyuwono, 2006).

Oleh sebab itu sudah banyak pemikir yang mencoba memberikan alternatif akuntansi. Dalam Harahap (2008) disebutkan beberapa pemikir yang mencoba memberikan alternatif yaitu Hayashi (1989) ia mengemukakan beberapa school of thought paradigma baru misalnya: British Critical Accounting School, Political economy of accounting, Hopwood's alternative accounting theory, Gambling's Societal accounting. Kemudian Triyuwono (2000) mengemukakan beberapa pemikiran akuntansi yang berada di luar mainstream yang dilandasi system klasik Amerika misalnya: Paradigma interpretif yang dimotori Preston, 1986, Paradigma kritikal yang disponsori Tinker, 1984, 1988, Tinker, Merino, dan Neimark, 1982, dan paradigma Pascamodernisme yang disampaikan oleh Arrington dan Francis, 1989, Rasyid, 1995, Triyuwono, 1998. Dalam diri disiplin akuntansi konvensional itu sendiri lahir beberapa konsep yang keluar dari mainstreamnya seperti munculnya Socio - economic accounting, environmental accounting, employee reporting, human resources accounting, value added reporting, Islamic accounting dan current cost accounting (Belkaoui, 1984, Harahap, 
2003). Sedangkan dalam bidang ekonomi banyak pemikir yang sudah memberikan jalan alternatif misalnya MA Choudhury (1997) Umer Chapra (1992, 2000), MA Manan (2000) dengan Ekonomi Syariahnya, dari Kristen Ashford dan Shakespeare (1999) dengan Binary Economics, dari Buddha EF Schumacher dengan motto dan judul bukunyanya Small is beautiful (Harahap, 2008).

Sementara itu Ludigdo (2005), mengeksplorasi secara konsepsional tentang upaya yang mungkin dikembangkan dalam mendorong praktik etis di kantor akuntan publik (KAP). Dengan melakukan sintesa atas beberapa konsep dan teori, etika dapat dikembangkan di KAP dengan pola yang lebih komprehenship. Pengembangan praktik etika dapat dilakukan baik melalui pola yang eksplisit maupun implisit, dengan memperhatikan pengembangan potensi emosionalitas (EQ) dan spiritualitas (SQ) individu anggota organisasi KAP (Ludigdo, 2005).

Dari uraian diatas, maka saya tertarik untuk mencoba menjelaskan betapa etika sangat diperlukan dalam akuntansi, terutama kesadaran diri dari pada para akuntan untuk bersikap etis. Kesadaran diri ini dapat diperoleh dari pemahaman dan pengalaman spiritual seseorang. Dan pada makalah ini dijelaskan bagaimana Islam menekankan pentingnya etika dalam akuntansi. Makalah ini merupakan telaah literatur yang penulis kumpulkan.

\section{Definisi Etika}

Asal kata etika diambil dari bahasa Yunani yaitu ethos (bentuk tunggal) yang berarti: tempat tinggal, padang rumput, kandang, kebiasaan, adat, watak, perasaan, sikap, cara berpikir. Bentuk jamaknya adalah ta etha, yang berarti adat istiadat. Dalam hal ini, kata etika sama pengertiannya dengan moral (Agoes dan Ardana, 2009).

Menurut Kamus Bahasa Indonesia terbitan Departemen Pendidikan dan Kebudayaan (1988), etika merupakan :

a. Ilmu tentang apa yang baik dan apa yang buruk, dan tentang hak dan kewajiban moral (akhlak).

b. Kumpulan asas atau nilai yang berkenaan dengan akhlak.

c. Nilai mengenai benar dan salah yang dianut suatu golongan atau masyarakat.

Sedangkan Beekun (2004) mendefinisikan etika sebagai seperangkat prinsip moral yang membedakan yang baik dari yang buruk. Ia menyatakan etika adalah bidang ilmu yang bersifat normatif karena ia berperan menentukan apa yang harus dilakukan atau tidak boleh dilakukan oleh seorang individu.

Selanjutnya Beekun menyatakan bahwa dalam Islam, istilah yang paling dekat berhubungan dengan istilah etika di dalam Al-Qur'an adalah khuluq. Al-Qur'an juga mempergunakan sejumlah istilah lain untuk menggambarkan konsep tentang :khayr (kebaikan), birr (kebenaran), qist (persamaan), 'adl (kesetaraan dan keadilan), haqq (kebenaran dan kebaikan), ma'ruf (mengetahui dan menyetujui), dan taqwa (ketakwaan). Tindakan yang terpuji disebut sebagai salihat dan tindakan yang tercela disebut sebagai sayyi'at.

Dalam ajaran Islam, etika menuntun seluruh aspek kehidupan manusia. Kesuksesan tertinggi yang akan diperoleh seorang Muslim atau falah dalam Islam adalah sama bagi setiap muslim, baik saat menjalankan bisnis ataupun saat menjalankan aktivitas sehari-hari mereka. Allah menggambarkan orang yang mencapai kesuksesan sebagai orang-orang yang mengarahkan semua tindakannya kepada kebaikan (khayr), mendorong 
kepada yang benar (ma'ruf), dan melarang kepada yang salah (munkar).

Triyuwono (2006) menyatakan teori etika yang berdasar pada nilai agama memberikan sebuah konsep yang menyatakan bahwa pelaku tindakan yang baik dan benar menurut agama akan mendapat pahala sedangkan jika ia melakukan perbuatan yang tidak dibenarkan oleh agama ia akan mendapat dosa, sehingga ini memberikan suatu keyakinan bahwa berbuat kebajikan merupakan jalan menuju sorga dan begitu pula sebaliknya perbuatan dosa akan menggiring pelakunya pada siksa yang pedih. Sedangkan teori etika yang sekuler, konsep semacam ini tidak ditemukan, karena ruang lingkup yang menjadi kajian mereka terbatas pada objek yang secara empiris dapat diketahui dan secara nalar dapat dipertanggung jawabkan.

\section{Islam Sebagai Agama yang Komprehensif}

Agama Islam adalah agama dan pandangan hidup yang komprehensif dan universal serta terpadu. Islam sebagai agama yang universal berarti aturan-aturan, penjelasan-penjelasan, perintahperintah, larangan-larangan serta seruan atau anjurannya berlaku untuk seluruh alam semesta beserta isinya, termasuk pada seluruh manusia yang tidak terbatas pada umat Islam dan sampai hari akhir (kiamat) nanti.

Harahap (2001) menyatakan bahwa berdasarkan berbagai penelitian yang dilakukan di Barat, ternyata konsepsi Islam yang diturunkan kepada manusia oleh Allah SWT melalui Rasulullah SAW merupakan suatu sistem way of life yang utuh, sesuai dan tidak bertentangan dengan ilmu pengetahuan serta fenomena alam yang ada. Dalam Al-Qur'an banyak didapati penjelasan Allah SWT tentang keuniversalan Islam diantaranya didalam surat Al Baqarah ayat 21 :

"Hai, manusia! Sembahlah

Tuhan yang menjadikan kamu dan orang-orang sebelum kamu supaya kamu menjadi bertakwa" (QS: 2 :21)

dan di ayat 185 yang berbunyi :

"(Puasa itu) dalam bulan Ramadhan, bulan diturunkan AlQur'an, menjadi petunjuk bagi manusia, memberi penjelasan petunjukpetunjuk itu dan menjadi pemisah/pembeda (antara yang hak dan batil).." (QS: 2: 185).

Agama Islam tidak hanya mengatur bagaimana umat beribadah kepada Tuhannya saja akan tetapi ia juga mengatur keseluruhan hidup manusia, bagaimana hubungan antar manusia (manusia dengan manusia) dan bagaimana hubungan manusia dengan alam sekitarnya/ lingkungan. Agama Islam tidak hanya mengatur urusan dunia saja akan tetapi juga jauh kedepan mengatur urusan akhirat yaitu hari pengadilan.

Islam sebagai agama dan pandangan hidup yang komprehensif atau lengkap dapat ditunjukkan dengan ayat-ayat Al-qur'an yang apabila dikelompokkan akan mengatur diantaranya tentang aqidah, etika, akhlak, ibadah dan muamalah. Pilar Islam adalah aqidah, syariah dan akhlaq. Aqidah sebagai landasan keimanan muslim (tauhid) yang menjiwai syariah (hukum-hukum Islam) dan aturanaturan mengenai moralitas umat (akhlaq). Syariah mendasari muamalah dan ibadah. Muamalah adalah kegiatan umat yang menyangkut hubungan antara manusia dengan manusia, manusia dengan binatang, tumbuhtumbuhan, bumi, laut, udara dan makhluk Allah lainnya (Wiyono, 2005). 
Islam Sebagai Suatu Sistem Nilai

Nilai menurut Webster's

(1996) dalam Wiyono, 2005 adalah

sesuatu (sebagai suatu prinsip atau kualitas ) yang intinya berharga atau dibutuhkan. Sedangkan sistem nilai adalah suatu kumpulan item (nilai) yang secara teratur berinteraksi atau saling tergantung yang membentuk suatu kesatuan unik. Islam dengan Al-Qur'an sebagai kitab sucinya, berisi tentang nilai-nilai kebenaran, keimanan, hukum, etika, akhlak dan sebagainya. Prinsipprinsip dalam Islam sangat berharga dan dibutuhkan dalam kehidupan di dunia dan di akhirat. Sedangkan Islam sebagai suatu sistem nilai dapat diartikan bahwa Islam merupakan suatu kumpulan prinsip Islam yang berharga, yang secara teratur berinteraksi atau saling tergantung yang membentuk suatu kesatuan yang unik.

Jadi dalam Islam prinsipprinsip aqidah, beretika, berakhlak, bermuamalah, dan beribadah merupakan satu kesatuan yang tidak dapat dipisahkan dan memiliki ketergantungan antara satu prinsip dengan prinsip lainnya. Jika manusia melakukan muamalah maka dasarnya adalah nilai-nilai syariah, sedangkan syariah dijiwai oleh nilai-nilai aqidah atau tauhid. Apabila nilai Islam dijalankan, maka akan membentuk manusia yang memiliki akhlaqul karimah atau berbudi pekerti luhur. Manusia yang berbudi pekerti yang luhur akan mempunyai niat, berpikir dan bertindak berdasarkan dan dijiwai oleh nilai-nilai aqidah, syariah dan akhlak sehingga buah pikir dan tindakannya akan memberikan kemaslatan bagi semua pihak.

Islam juga mengatur tentang aspek dan nilai dari professi akuntan. Islam menginginkan agar Akuntansi tidak hanya memikirkan kepentingan kapitalis saja, tidak juga hanya berfikir dunia, tetapi dia juga harus bisa menghantarkan semua pihak baik manajemen, karyawan, inverstor, analis dan akuntan menuju keselamatan dan kemenangan dunia dan akhirat (alfalaah) (Harahap, 2008).

Sementara itu Triyuwono (1996) dalam Muhammad (2005) menyatakan dalam tradisi Islam seluruh etika yang dijadikan kerangka bisnis, dibangun atas dasar syariah. Syariah merupakan pedoman yang digunakan oleh umat Islam untuk berperilaku dalam segala aspek kehidupan.

Dalam masyarakat Muslim, akuntansi seharusnya dipengaruhi oleh cara sistem ekonomi yang diatur dari filosofi yang mendasari sistem. Berbeda dengan filsafat Barat sekuler seperti dicontohkan oleh Kant, di mana penekanan etika lebih pada rasionalitas pencerahan dan keyakinan yang kuat dalam kekuatan akal budi. Pandangan dunia Islam tidak hanya berasal dari unsur-unsur budaya dan filosofis dibantu oleh ilmu pengetahuan, tapi dari satu sumber yang asli yakni "Wahyu", dikonfirmasi oleh agama, dan ditegaskan oleh prinsipprinsip intelektual dan intuitif (Abdur Rahman, 2003).

Keberadaan akuntansi di dalam suatu masyarakat sangat dipengaruhi oleh banyak faktor seperti sistem ekonomi, sosial, politik, peraturan perundang-undangan, kultur, persepsi dan nilai yang berlaku dalam masyarakat mempunyai pengaruh yang besar terhadap bentuk akuntansi ( Schroeder dkk, 2009 ). Hal ini membuktikan bahwa akuntansi adalah sebuah keutuhan atau entitas (entity) informasi yang tidak bebas nilai karena dipengaruhi oleh banyak faktor tersebut. Namun pada akhir tahun 1970-an telah teradi perubahan-perubahan besar terhadap keberadaan ilmu akuntansi menuju proses harmonisasi penerapan akuntansi ( Schroeder dkk, 2009 ).

Islam sebagai suatu agama yang memiliki ajaran menyeluruh tidak tinggal diam dalam membangun 
paradigma ilmu yang sesuai dengan nilai-nilai Islam itu sendiri. Karena nilai-nilai yang berkembang dalam masyarakat Islam dan Barat terdapat perbedaan yang sangat besar. Dalam masyarakat Islam terdapat sistem nilai yang melandasi setiap aktivitas masyarakat, pribadi maupun komunal. Hal ini tidak ditemukan dalam kehidupan masyarakat Barat. Perbedaan dalam budaya dan sistem nilai ini menghasilkan bentuk masyarakat, praktik, serta pola hubungan yang berbeda pula (Nasution,2008).

Menurut Widiastomo (2009) Islam merupakan sumber nilai dan etika dalam segala aspek kehidupan manusia secara menyeluruh, termasuk wacana bisnis. Islam memiliki wawasan yang komprehensif tentang etika bisnis. Mulai dari prinsip dasar, pokok-pokok kerusakan dalam perdagangan, faktorfaktor produksi, tenaga kerja, modal organisasi, distribusi kekayaan, masalah upah, barang dan jasa, kualifikasi dalam bisnis, sampai kepada etika sosio ekonomik menyangkut hak milik dan hubungan sosial.

Selain itu dalam organisasi bisnis aspek yang berperanan penting adalah akuntansi, ini dikarenakan akuntansi tidak saja mempengaruhi perilaku manajemen, pemegang saham, karyawan dan masyarakat sekelilingnya, akan tetapi juga mempengaruhi organisasi yang bersangkutan Muhammad, 2005).

Menurut, Toshikabu Hayashi dalam tesisnya yang berjudul "On Islamic Accounting”, Akuntansi Barat (Konvensional) memiliki sifat yang dibuat sendiri oleh kaum kapital dengan berpedoman pada filsafat kapitalisme, sedangkan dalam Akuntansi Islam ada "meta rule" yang berasal diluar konsep akuntansi yang harus dipatuhi, yaitu hukum Syariah yang berasal dari Tuhan yang bukan ciptaan manusia, dan Akuntansi Islam sesuai dengan kecenderungan manusia yaitu "hanief" yang menuntut agar perusahaan juga memiliki etika dan tanggung jawab sosial, bahkan ada pertanggungjawaban di akhirat, dimana setiap orang akan mempertanggungjawabkan tindakannya di hadapan Tuhan yang memiliki Akuntan sendiri (Rakib dan Atid) yang mencatat semua tindakan manusia bukan saja di bidang ekonomi, tetapi juga bidang sosial-masyarakat dan pelaksanaan hukum Syariah lainnya(Gamal,2008).

\section{Akuntansi Dalam Al-Qur'an}

Dalam Harahap

menyatakan sesuai dengan penjelasan Hayashi (1989) Akutansi dalam bahasa Arab disebut Muhasabah terdapat 48 kali disebut dalam Alquran. Kata Muhasabah memiliki 8 pengertian:

1. Yahsaba yang berarti menghitung, to compute, atau mengukur atau to mensure.

2. Juga berarti pencatatan dan perhitungan perbuatan seseorang secara terus menerus.

3. Hasaba adalah selesaikan tanggung jawab

4. Agar supaya bersifat netral

5. Tahasaba berarti menjaga

6. Mencoba mendapatkan

7. Mengharapkan pahala diakhirat.

8. Menjadikan perhatian atau mempertanggungjawabkan.

Selain itu di dalam Al-Qur'an juga terdapat beberapa ayat yang menyangkut tentang masalah muamalah. Muamalah adalah kegiatan berjual-beli, utang-piutang dan sewamenyewa. Salah satunya adalah Surat Al-Baqarah ayat 282 yang merupakan ayat terpanjang dalam Al-Qur'an menyatakan :

"Hai orang-orang yang beriman, apabila kamu bermuamalah tidak secara tunai untuk waktu yang ditentukan, hendaklah seorang penulis di antara kamu menuliskannya dengan 
benar. Dan janganlah penulis enggan menuliskannya sebagaimana Allah telah mengajarkannya, maka hendaklah ia menulis, dan hendaklah orang yang berhutang itu mengimlakkan apa yang ditulis itu, dan hendaklah ia bertakwa kepada Allah Tuhannya, dan janganlah ia mengurangi sedikitpun daripada utangnya. Jika yang berutang itu orang yang lemah akal atau lemah keadaannya atau dia sendiri tidak mampu mengimlakkan, maka hendaklah wakilnya mengimlakkan dengan jujur dan persaksikanlah dengan dua orang saksi dari orang laki-laki di antara kamu. Jika tidak ada dua orang lakilaki maka bolehlah seorang laki-laki dan dua orang perempuan dari saksi yang kamu ridhoi, supaya jika seorang lupa seorang lagi mengingatkannya. Janganlah saksi itu enggan memberi keterangan apabila mereka dipanggil, dan janganlah kamu jemu menuliskan utang itu, baik kecil maupun besar sampai waktu membayarnya. Yang demikian itu lebih adil disisi Allah dan lebih dapat menguatkan persaksian dan lebih dekat kepada tidak menimbulkan keraguan. (Tulislah muamalahmu itu) kecuali jika muamalahmu itu perdagangan tunai yang kamu jalankan di antara kamu, maka tidak ada dosa bagi kamu jika kamu tidak menuliskannya. Dan persaksikanlah apabila kamu berjual-beli, dan janganlah penulis dan saksi saling sulit menyulitkan. Jika kamu lakukan yang demikian itu maka sesungguhnya hal itu adalah kefasikan pada dirimu. Dan bertakwalah kepada Allah. Allah mengajarmu dan Allah maha mengetahui segala sesuatu."

Dari ayat ini dapat kita ketahui bahwa ternyata Al-Qur'an telah menjelaskan fungsi-fungsi pencatatan (Kitabah) dalam bermuamalah (bertransaksi), penunjukan seorang pencatat beserta saksinya, dasar- dasarnya, dan mamfaat-manfaatnya seperti yang diterangkan oleh kaidahkaidah hukum yang harus dipedomani dalam hal tersebut.

Gamal (2008) menyatakan bahwa kaidah Akuntansi dalam konsep Islam dapat didefinisikan sebagai kumpulan dasar-dasar hukum yang baku dan permanen, yang disimpulkan dari sumber-sumber Syariah Islam dan dipergunakan sebagai aturan oleh seorang Akuntan dalam pekerjaannya, baik dalam pembukuan, analisis, pengukuran, pemaparan, maupun penjelasan, dan menjadi pijakan dalam menjelaskan suatu kejadian atau peristiwa.

Dengan demikian dapat kita ketahui bahwa ternyata Islam lebih dahulu mengenal sistem akuntansi, karena Al Quran telah diturunkan pada tahun 610M, yakni 800 tahun lebih dahulu dari Luca Pacioli yang menerbitkan bukunya pada tahun 1494M (Harahap, (2001); Triyuwono,( 2006); Muhammad, (2005) dan, Gamal (2008).

\section{Nilai -nilai Etika Dalam Akuntansi Dilihat Dari Sudut Pandang Islam}

1. Nilai Etika yang terdapat dalam pencatatan

Berdasarkan Surat Al-Baqarah ayat 282 diatas kita dapat mengetahui bahwa Allah memerintahkan untuk melakukan pencatatan atau penulisan transaksi (muamalah) secara benar dan jujur atas semua transaksi yang terjadi selama melakukan muamalah. Transaksi merupakan segala sesuatu yang mengakibatkan perubahan terhadap aktiva dan pasiva individu atau organisasi (perusahaan). Pencatatan transaksi tersebut harus berdasarkan bukti seperti faktur, surat utang, checks, kwitansi dan lain sebagainya. Kita dilarang untuk mengurangi atau menambah transaksi tersebut. Ini dimaksudkan untuk menhindari fraud atau kecurangan. 
Harahap (2001) menyatakan bahwa menurut Islam yang dianggap sebagai bukti adalah bukti yang didukung oleh sifat-sifat kebenaran tanpa ada penipuan. Dalam akuntansi ada jenis dan tingkatan bukti yang menandakan kuat-tidaknya suatu bukti, yaitu : Real Eviden, yaitu bukti fisik, Testimonial Eviden yaitu bukti yang berasal dari kesaksian pihak luar dan Indirect Eviden yaitu bukti yang diperoleh secara tidak langsung. Bukti yang diperoleh dari luar perusahaaan lebih kuat dibandingkan bukti yang diperoleh dari dalam sendiri. Bukti yang diperoleh dari sistem Internal Control perusahaan yang baik lebih kuat dari yang diperoleh dari Internal Control yang lemah. Dan bukti yang diperoleh secara langsung oleh Akuntan lebih kuat dari bukti yang diperoleh secara tidak langsung.

Dalam Islam bukti yang diinginkan adalah bukti yang benar ini sejalan dengan akuntansi yang menginginkan pencatatan dengan bukti yang valid. Sehingga dengan adanya pencatatan atau penulisan tersebut dapat dijadikan sebagai informasi untuk menentukan apa yang akan diperbuat oleh seseorang dan ketika terjadi perselisihan diantara mereka pencatatan tersebut dapat menjadi bukti di tambah lagi diperkuat dengan adanya saksi.

Dari Surat Al-Baqarah ayat 282 ini dapat kita ketahui bahwa Islam menekankan kewajiban untuk melakukan pencatatan dalam bermuamalah atau bertransaksi agar :

1. Pencatatan tersebut akan menjadi bukti dilakukannya muamalah atau transaksi dan pencatatan ini menjadi dasar dalam menyelesaikan persoalan selanjutnya.

2. Dengan adanya pencatatan ini maka akan mencegah terjadinya manipulasi atau penipuan, baik dalam transaksi maupun hasil dari transaksi itu (laba).
Hal ini sesuai dengan tujuan pencatatan akuntansi yaitu

1. Pertanggungjawaban (accountability) atau sebagai bukti transaksi.

2. Penentuan pendapatan (income determination)

3. Informasi yang digunakan dalam proses pengambilan keputusan, dan lain-lain.

Akuntansi merupakan upaya untuk menjaga terciptanya keadilan dalam masyarakat, karena akuntansi memelihara catatan sebagai accountability dan menjamin akurasinya. Pentingnya keadilan ini dapat dilihat dari Al- Qur'an Surat AlHadiid ayat 24 sebagai berikut :

"Sesungguhnya kami telah mengutus rasul-rasul kami dengan membawa bukti yang nyata dan telah kami turunkan bersama mereka Al Kitab dan Neraca (keadilan) supaya manusia dapat melaksanakan keadilan."

2. Nilai Etika yang terdapat dalam pengukuran

Akuntansi adalah ilmu informasi yang mencoba mengkonversi bukti dan data menjadi informasi dengan cara melakukan pengukuran atas berbagai transaksi dan akibatnya yang dikelompokkan dalam account, perkiraan atau pos keuangan seperti aktiva, utang, modal, hasil, biaya, dan laba (Gamal, 2008).

Jika kita membaca Al- Quran akan kita dapati ayat yang menyatakan bahwa kita harus mengukur secara adil, jangan dilebihkan dan jangan dikurangi. Kita dilarang untuk menuntut keadilan ukuran dan timbangan bagi kita, sedangkan bagi orang lain kita menguranginya (Gamal, 2008). Menyangkut hal ini, Al Quran menyatakan dalam berbagai ayat, antara 
lain dalam surat Asy-Syu'ara ayat 181184 yang berbunyi:

"Sempurnakanlah takaran dan janganlah kamu termasuk orangorang yang merugikan dan timbanglah dengan timbangan yang lurus (benar). Dan janganlah kamu merugikan manusia pada hak-haknya dan janganlah kamu merajalela di muka bumi dengan membuat kerusakan dan bertakwalah kepada Allah yang telah menciptakan kamu dan umat-umat yang dahulu."

Sesuai dengan perintah Allah dalam Al Quran, kita sebagai akuntan harus menyempurnakan pengukuran atas pos-pos yang disajikan dalam Neraca, sebagaimana digambarkan dalam Surah Al-Israa' ayat 35 yang berbunyi:

"Dan sempurnakanlah takaran apabila kamu menakar, dan timbanglah dengan neraca yang benar. Itulah yang lebih utama (bagimu) dan lebih baik akibatnya."

Menurut Chapra dalam Gamal (2008) kebenaran dan keadilan dalam mengukur (menakar) tersebut juga menyangkut pengukuran kekayaan, utang, modal pendapatan, biaya, dan laba perusahaan, sehingga seorang Akuntan wajib mengukur kekayaan secara benar dan adil. Agar pengukuran tersebut dilakukan dengan benar, maka perlu adanya fungsi auditing. Gamal (2008), menyatakan bahwa dalam Islam, fungsi Auditing ini disebut "tabayyun" sebagaimana yang dijelaskan dalam Surah Al-Hujuraat ayat 6 yang berbunyi:

"Hai orang-orang yang beriman,jika datang kepadamu orang fasik membawa suatu berita, maka periksalah dengan teliti, agar kamu tidak menimpakan suatu musibah kepada suatu kaum tanpa mengetahui keadaannya yang menyebabkan kamu menyesal atas perbuatanmu itu."

3. Nilai Etika yang terdapat dalam laporan akuntansi

Laporan akuntansi merupakan wujud dari pertanggungjawaban (accountability) dari pihak manajemen yang telah diberi amanat kepada pihakpihak yang terkait yang memiliki kepentingan. Dalam Al-Qur'an sendiri banyak yang menjelaskan tentang proses pertanggungjawaban manusia sebagai pelaku amanah Allah di muka bumi (Muhammad, 2002)

Etika dalam laporan akuntansi ini dapat dilihat dari Harahap (2001) yang menyatakan bahwa penggunaan sistem akuntansi jelas merupakan manifestasi dari pelaksanaan perintah surat Asy-Syuraa ayat 181-184. Karena sistem akuntansi dapat menjaga agar asset yang dikelola terjaga accountability-nya sehingga tidak ada yang dirugikan, jujur, adil dan kepada yang berhak akan diberikan sesuai dengan haknya.

Menurut Muhammad (2002)

dalam Surat Al-Baqorah ayat 282 terdapat kata adil dan benar. Kata keadilan dalam konteks aplikasi akuntansi mengandung dua pengertian, yaitu : Pertama, adalah berkaitan dengan praktik moral, yaitu kejujuran yang merupakan faktor yang sangat dominan. Tanpa kejujuran ini, informasi akuntansi yang disajikan akan menyesatkan dan sangat merugikan masyarakat. Kedua, kata adil bersifat lebih fundamental (dan tetap berpijak pada nilai-nilai etika/ syariah dan moral).

Sedangkan kebenaran menurut Muhammad (2002) tidak dapat dilepaskan dengan keadilan. Aktivitas pengakuan, pengukuran dan pelaporan dapat dilakukan dengan baik jika dilandaskan pada nilai kenaran dan kebenaran ini akan dapat menciptakan 
keadilan dalam mengakui, mengukur dan melaporakan transaksi-transaksi ekonomi. Menurut Harahap (2001) laporan akuntansi didukung oleh bukti (eviden) yang tidak ada transaksi yang di lupakan atau dihilangkan walaupun sekecil apapun, seperti dilihat dari surat Al-Zalzalah ayat 7-8 :

"Barangsiapa yang mengerjakan kebaikan sebesar zarrah pun niscaya akan melihatnya. Dan barangsiapa mengerjakan kejahatan sebesar zarrahpun dia akan melihatnya."

Dalam Islam, akuntansi tidak hanya berfungsi sebagai kegiatan pelayanan memberikan informasi keuangan kepada pengguna dan untuk masyarakat pada umumnya, tetapi yang lebih penting, laporan keuangan tersebut harus dapat dipertanggungjawabkan kepada Tuhan dan dengan memberikan informasi tersebut memungkinkan masyarakat untuk mengikuti perintahperintah allah, yang salah satunya adalah mengeluarkan zakat.

\section{Kesimpulan}

Akuntansi dalam Islam termasuk kedalam urusan muamalah oleh karena itu pengembangannya diserahkan pada kebijaksanaan manusia, karena pada dasarnya semua aktivitas muamalah adalah boleh kecuali ada dalil yang melarangnya. Karena Islam adalah agama yang bersifat menyeluruh, oleh sebab itu dalam melaksanakan transaksi atau muamalah tidak boleh bertentangan dengan Al-Qur'an dan Sunnah. Al-Qur'an dan Sunnah telah memberikan bekal untuk bermuamalah itu dengan beberapa sistem nilai seperti keadilan, kebenaran, kejujuran, bertanggungjawab, terpercaya, kewajiban bertakwa, menyatakan yang benar, memilih yang terbaik, berguna, menghindari yang haram, jangan boros, jangan merusak, jangan menipu dan lain sebagainya. Jadi jelas sekali akuntansi dalam pandangan Islam sangat sarat dengan nilai-nilai etika dan moral. Jika ini benar-benar diterapkan, maka berbagai macam tindakan penipuan, kecurangan, penyuapan, kerja sama antara akuntan publik dengan kliennya yang merugikan masyarakat dan tindakan yang melanggar etika lainnya tidak akan terjadi.

\section{Daftar Pustaka}

Agus,Sukrisno dan Ardana, I Cenik. 2009. Eika Bisnis dan Profesi Tantangan Membangun Manusia Seutuhnya. Jakarta :Salemba Empat

American Accounting Association (1977). A Statement of Basic Accounting

Theory (ASOBAT)

Al-Qur'an dan Terjemahannya, DEPAG, RI

Beekun, Rafik Issa. 2004. Etika Bisnis Islami (Terjemahan). Pustaka Pelajar Yogyakarta.

Doost, Roger K. and Fishman,Teddi. 2004. Beyond Arthur Andersen Searching for answers. Managerial Auditing Journal Vol. 19 No. 5, 2004 pp. 623-639

Gaffikin,Michael.2008. Accounting Theory Research, Regulation and Accounting Practice. Pearson Education Australia.

Gamal, $\begin{aligned} & \text { Merza. Akuntansi Dalam } \\ & \text { Pandangan }\end{aligned}$
http://himasi.blogspot.com
Diakses 1 Juni 2010.




\section{Harahap, Sofyan Syafri (1992). Akuntansi Pengawasan Manajemen Dalam Perspektif Islam. FE Trisakti Jakarta.}

(1999).Akuntansi Islam, Bumi Aksara, Jakarta

(2001). Teori Akuntansi Edisi Revisi. PT RajaGrafindo Persada Jakarta.

(2008) Pentingnya Unsur Etika dalam Profesi Akuntan dan Bagaimana di Indonesia ?. Jurnal EKBISI.

(2008).Akuntansi Sosial Ekonomi.

http://Sofyan.syafri.com diakses 22-05-2010

Kamus Bahasa Indonesia Terbitan Departemen Pendidikan dan Kebudayaan (1988).

Ludigdo,Unti.2005. Mengembangkan Etika di Kantor Akuntan Publik: Sebuah Perspektif untuk Mendorong Perwujudan Good Governance. Makalah disampaikan dalam Konferensi Nasional Akuntansi "Peran Akuntan dalam Membangun Good Corporate Governance"di Universitas Trisakti, 24 September 2005.

2007. Paradoks Etika Akuntan. Pustaka Pelajar Yogyakarta.

Nasution ,Ahmad Sanusi.2008 Akuntansi Syariah Dalam
Sebuah

Tinjauan.

http://sanoesi.wordpress.com

Mayangsari, Sekar dan Wilopo, 2002.

Konservatisme Akuntansi,

Value Relevance dan Discretionary Accruals: Implikasi Empiris Model Feltham-Olhson (1996). Jurnal Riset Akuntansi Indonesia, vol.5, no.3 (September), Hal : 291-310.

Muhammad. 2002. Pengantar Akuntansi Syariah. Penerbit Salemba Empat Jakarta. 2005. Pengantar Akuntansi Syariah Edisi 2. Penerbit Salemba Empat Jakarta.

Schroeder,R.G, M.W Clark, dan J.W Cathey (2009). Financial Accounting Theory and Analysis-text and cases. Iohn Willey\& Sons, Inc, USA

Tonge,Alyson; Geer, Lesley and Lawton,Alan. 2003.The Enron Story: You can Fool Some of the People Some of the Time...Business Ethics : A European Review, vol.12, no.1 (January).

Triyuwono, Iwan. 2006. Perspektif, Metodologi, dan Teori Akuntansi Syariah. PT RajaGrafindo Persada Jakarta.

Widiastomo, Yusro.2009. Etika Bisnis dalam Islam. 